\title{
SISTEM INFORMASI SARANA DAN PRASARANA SEKOLAH BERBASIS WEBSITE SMK BAKTI PURWOKERTO
}

\author{
Ari Priono $^{1)}$, Dwi Krisbiantoro ${ }^{2)}$, Bagus Adhi Kusuma ${ }^{3)}$ \\ ${ }^{1,2)}$ Sistem Informasi, ${ }^{3)}$ Informatika, Fakultas Ilmu Komputer, Universitas AMIKOM Purwokerto \\ email : aripriyono5678@gmail.com $^{1)}, \underline{\text { dwikris@amikompurwokerto.ac.id }}^{2)}, \underline{\text { bagus@amikompurwokerto.ac.id }}^{31}$
}

\begin{abstract}
Abstraksi
SMK Bakti Purwokerto merupakan salah satu Sekolah Menengah Kejuruan (SMK) di Banyumas yang berdiri sejak 1 Januari 1968 dengan beralamat di Jl. Dr. Soeparno No. 13 Purwokerto, Kabupaten Banyumas, Jawa Tengah, 53111. Di sekolah tersebut pengelolaan barang sarana dan prasarana saat ini masih menggunakan cara manual yaitu dengan pencatatan di buku. Pengelolaan barang dengan cara seperti ini menyebabkan kurang maksimalnya dalam pengelolaan Sarana dan Prasarana yang ada. Beberapa masalah lainnya yaitu sulitnya bagian staf Wakil Kepala Sarana dan Prasarana dalam proses pencarian informasi barang, karena tidak lengkap dan detailnya data pada proses pembukuan. Oleh karena itu, barang pada Sarana dan Prasarana yang telah berpindah tempat atau dipinjam sangat sulit untuk diketahui keberadaannya. Sistem informasi berbasis website menggunakan metode kualitatif. Metode ini bersifat sistem dengan metode prototype sebagai pengembangan sistemnya. Hasil dari penelitian ini yaitu membuat suatu sistem informasi sarana dan prasarana sekolah berbasis website pada SMK Bakti Purwokerto dengan tujuan dapat membantu staf Wakil Kepala Sarana dan Prasarana mulai dari proses pencarian barang menggunakan scan QR Code, perekapan laporan hingga mengelompokkan data sarana prasarana. Kesimpulan dari pengujian Acceptance Testing atau istilah dari Beta Testing dihasilkan $88,65 \%$ yaitu masuk ke dalam kategori sangat baik terhadap sistem yang di usulkan.
\end{abstract}

Kata Kunci : Sistem Informasi, Sarana dan Prasarana, Sekolah, Prototype.

\begin{abstract}
Bakti Purwokerto Vocational School is one of the Vocational High Schools (VHS) in Banyumas which was established on January 1, 1968 with its address at Jl. Dr. Soeparno No. 13 Purwokerto, Banyumas Regency, Central Java, 53111. At the school the management of goods and infrastructure is currently still using manual methods, namely by recording in books. Management of goods in this way causes less than maximum management of existing facilities and infrastructure. Some other problems are the difficulty of the Deputy Chief of Facilities and Infrastructure staff in the process of finding information on goods, due to incomplete and detailed data in the bookkeeping process. Therefore, the goods in the Facilities and Infrastructure that have been moved or borrowed are very difficult to find out. Website-based information systems use qualitative methods. This method is a system with a prototype method as the development of the system. The results of this study are creating a website-based school infrastructure and information system at the Bakti Purwokerto Vocational School with the aim of being able to assist the Deputy Head of Facilities and Infrastructure starting from the process of searching for goods using a QR Code scan, recording reports to grouping infrastructure data. The conclusion of the Acceptance Testing or the term from Beta Testing produced $88.65 \%$ which is included in the excellent category of the proposed system.
\end{abstract}

\section{Keywords : Information Systems, Facilities and Infrastructure, Schools, Prototypes.}

\section{Pendahuluan}

Penerapan Sistem Informasi (SI) dalam organisasi menyediakan berbagai contoh sukses yang dapat memberikan keuntungan kepada organisasi dan para pegawai yang bekerja untuk organisasi tersebut. Sudut pandang yang harus lebih dilihat adalah bahwa mengimplementasikan sistem informasi dalam organisasi yaitu merupakan sesuatu yang lebih dari sekedar menjalankan dan menggunakan sebuah produk, tapi juga mengubah cara berpikir dan cara bekerja pegawai. Jika dilihat lebih personal, pembelajaran menunjukkan bahwa sikap seseorang terhadap teknologi, berpengaruh terhadap penggunaan sistem informasi [1].

Suatu lembaga akan dapat berfungsi dengan memadai kalau memiliki sistem manajemen yang didukung dengan sumber daya manusia (SDM), dana/biaya, dan sarana-prasarana. Sarana pendidikan adalah semua perangkat peralatan, bahan dan perabot yang secara langsung digunakan dalam proses pendidikan di sekolah, seperti: buku, papan tulis, kursi, meja dan sebagainya. Sedangkan prasarana pendidikan adalah semua perangkat kelengkapan dasar yang secara tidak langsung menunjang proses pendidikan di sekolah [2]. 
Sekolah merupakan sebuah aktivitas besar yang di dalamnya ada empat komponen yang saling berkaitan. Empat komponen yang dimaksud adalah Staf Tata Laksana Administrasi, Staf Teknis Pendidikan di dalamnya ada Kepala Sekolah dan Guru, Komite sekolah sebagai badan independen yang membantu terlaksananya operasional pendidikan, dan siswa sebagai peserta didik yang bisa ditempatkan sebagai konsumen dengan tingkat pelayanan yang harus memadai. Hubungan keempatnya harus sinergis, karena keberlangsungan operasional sekolah terbentuknya dari hubungan "simbiosis mutualisme" keempat komponen tersebut karena kebutuhan akan pendidikan demikian tinggi, tentulah harus dihadapi dengan kesiapan yang optimal [2].

SMK Bakti Purwokerto merupakan salah satu Sekolah Menengah Kejuruan (SMK) di Banyumas yang berdiri sejak 1 Januari 1968 dengan beralamat di Jl. Dr. Soeparno No. 13 Purwokerto, Kabupaten Banyumas, Jawa Tengah, 53111. SMK Bakti Purwokerto memiliki 4 Bidang Keahlian, yaitu : Administrasi Perkantoran, Akuntansi, Multimedia, dan Tekhnik Komputer Jaringan.

Berdasarkan hasil wawancara dengan pihak staf waka sarana dan prasarana menuturkan bahwa dalam pengelolaan barang sarana dan prasarana di SMK Bakti Purwokerto saat ini masih menggunakan cara manual yaitu dengan pencatatan di buku. Pengelolaan barang dengan cara seperti ini menyebabkan kurang maksimalnya dalam pengelolaan Sarana dan Prasarana yang ada. Beberapa masalah lainnya yaitu sulitnya bagian staf Wakil Kepala Sarana dan Prasarana dalam proses pencarian informasi barang, karena tidak lengkap dan detailnya data barang pada proses pembukuan. Oleh karena itu, barang pada Sarana dan Prasarana yang telah berpindah tempat atau dipinjam sangat sulit untuk diketahui keberadaannya. Kemudian sulitnya petugas sarana dan prasarana dalam melakukan perekapan laporan sehingga dalam proses tersebut membutuhkan waktu yang relatif cukup lama karena petugas harus mengecek kembali data barang tersedia dan data kondisi barang yang sudah rusak maupun yang sedang membutuhkan pemeliharaan dengan membuka kembali berkasberkas alat dan peminjaman yang ada.

Adapun tujuan dari penelitian ini adalah untuk membangun sistem informasi sarana dan prasarana sekolah berbasis website pada SMK Bakti Purwokerto, dengan adanya sistem informasi ini dapat membantu staf sarana waka prasarana mulai dari proses pencarian barang menggunakan $Q R$ Code, perekapan laporan hingga mengelompokkan data sarana prasarana.

Beberapa batasan masalah yang dipertimbangkan untuk memfokuskan lingkup pembahasan dan pemahaman penelitian ini yaitu : Penelitian ini dilakukan pada bagian sarana dan prasarana SMK Bakti Purwokerto, Penelitian ini lebih difokuskan pada aktivitas pengelolaan barang sarana dan prasarana yang bergerak di SMK Bakti Purwokerto, Menggunakan metodologi prototype dalam pengembangan sistem, Sistem informasi dapat diakses secara online, Menggunakan teknik pelabelan Qr Code pada barang, Sistem informasi ini mengandung bahasa pemrograman PHP dan basis data $M y S Q L$, Pada sistem ini pengguna hanya dapat melihat laporan apa saja yang dipinjam oleh pengguna itu sendiri.

Penelitian yang dilakukan oleh [3] menjelaskan mengenai Aplikasi Peminjaman Sarana Dan Prasarana Berbasis Web di SMA Negeri 1 Baleendah. Aplikasi ini dapat membantu pihak sekolah melakukan kelola sarana dan prasarana, kelola peminjaman dan pengembalian, kelola user, serta kelola laporan. Pembuatan aplikasi ini dilakukan dengan metode Waterfall. Aplikasi berbasis web dan diimplementasikan berbasis website dengan menggunakan bahasa pemrograman PHP, dan basis data MySQL sebagai media penyimpanan data. Dengan adanya aplikasi ini, diharapkan dapat mempermudah pengelola dalam hal kelola sarana dan prasarana olahraga.

Maka untuk mengatasi masalah di atas, peneliti menuangkan ide untuk merancang sebuah sistem terkomputerisasi berbasis website. Website merupakan kumpulan dari halaman-halaman yang berhubungan dengan file-file lain yang saling terkait. Dalam sebuah website terdapat satu halaman yang dikenal dengan sebutan home-page. Homepage adalah sebuah halaman yang pertama kali dilihat ketika seseorang mengunjungi sebuah website [4].

Penggunaan teknik pelabelan $Q R$ Code pada barang digunakan dalam membangun sistem informasi sarana dan prasarana sekolah pada SMK Bakti Purwokerto ini karena untuk mempermudah Staf Wakil Kepala Sarana dan Prasarana dalam mengelompokkan barang dan memudahkan proses pengecekan. $Q r$ Code atau kode $Q R$ adalah salah satu jenis kode matriks atau kode batang dua dimensi yang dikembangkan Denso Wave [5].

Dengan dibangunnya sebuah sistem terkomputerisasi berbasis website bertujuan untuk memudahkan staf waka sarana dan prasarana dalam melakukan pencarian data yang dibutuhkan, pembuatan laporan serta pemeliharaan sarana prasarana yang lebih efektif dan efisien.

\section{Tinjauan Pustaka}

Berikut ini merupakan teori-teori yang menjadi pendukung dalam penelitian ini.

Sistem adalah sekumpulan elemen yang saling terkait atau terpadu yang dimaksudkan untuk mencapai suatu tujuan [6].

Informasi adalah data yang telah diolah menjadi sebuah bentuk yang berarti bagi penerimanya dan bermanfaat dalam pengambilan keputusan saat ini atau saat mendatang [6]. 
Sistem informasi adalah kumpulan komponen di dalam suatu organisasi yang berfungsi sebagai pengolahan untuk menghasilkan sebuah laporanlaporan yang disajikan kepada pihak tertentu [7].

Sarana dan Prasarana adalah semua alat yang secara langsung maupun tidak langsung digunakan untuk memperlancar proses bimbingan, pembelajaran, baik secara individu maupun kelompok, formal maupun non formal guna mengubah tingkah laku dan pengetahuan individu dalam menjalani kehidupannya di masyarakat [8].

Website adalah sebuah wadah atau media yang menampung beragam informasi untuk disampaikan kepada khalayak umum [9].

QR Code adalah image berupa matriks dua dimensi yang memiliki kemampuan untuk menyimpan data di dalamnya. Qr Code merupakan evolusi dari kode batang (barcode)[10].

Prototype adalah sistem perangkat lunak yang digunakan untuk mendemonstrasikan konsep-konsep, percobaan rancangan, dan menemukan lebih banyak masalah dan solusi yang memungkinkan [11].

Menurut [12] Unified Modelling Language (UML) adalah bahasa pemodelan untuk sistem atau perangkat lunak yang berparadigma 'berorientasi objek'.

Adapun penelitian-penelitian yang membahas tentang sistem informasi sarana dan prasarana sekolah berbasis website.

Penelitian tersebut yaitu dilakukan oleh [13]. Hasil dari penelitian ini berupa sistem manajemen sarana dan prasarana berbasis website yang bertujuan untuk membantu dinas pendidikan dalam pengelolaan data sarana dan prasarana yang ada. Penelitian ini menggunakan metode Object Oriented Analysis and Design (OOAD). Adapun kelemahannya penelitian ini belum ditambahkan tabel keterangan untuk gambar rusak ringan dan rusak berat.

Penelitian lain yang dilakukan oleh [14].Dalam penelitian ini membahas mengenai perancangan aplikasi pendataan sarana dan prasarana. Hasil dari penelitian ini yaitu perancangan aplikasi pendataan sarana dan prasarana menggunakan Data Flow Diagram sebagai penjelasan untuk memperlihatkan alur sistem yang akan berjalan. Adapun Kelemahan sistem ini yaitu hanya baru perancangan aplikasi.

Penelitian lainnya yang dilakukan oleh [15] membahas mengenai pengembangan sistem informasi sarana dan prasarana berbasis web. Untuk hasil dari penelitian ini yaitu dibangunnya sistem sarana dan prasarana yang bertujuan untuk membangun sistem pengelolaan data inventaris UTS berbasis web. Dalam pengembangannya menggunakan metode waterfall. Adapun kelemahan dari sistem ini yaitu user interface belum interaktif, kemudian diperlukan penyempurnaan untuk fitur proses peminjaman dan pengembalian.
Penelitian lainnya yang dilakukan oleh [16] yaitu membahas mengenai sistem informasi pengadaan sarana dan prasarana sekolah dengan menggunakan PHP. Untuk hasil dari penelitian ini yaitu dibangunnya sistem inventaris sarana dan prasarana berbasis website. Tujuan dari penelitian ini yaitu dapat mempermudah dan mempercepat pihak Tata Usaha dan Laboratorium dalam melakukan penginventarisasian barang. Sistem ini juga dilengkapi form peminjaman serta pengembalian barang. Kelemahan dari penelitian ini yaitu belum dilengkapi beberapa menu guna memenuhi kebutuhan sistem.

Penelitian lainnya yang dilakukan oleh [17] yaitu membahas mengenai prototyping software monitoring sarana dan prasarana. Dalam penelitian tersebut berfokus pada rancangan dari perangkat lunak yang perlu di bangun. Penelitian ini bertujuan untuk memfasilitasi sistem manajemen pemantauan program infrastruktur sarana dan prasarana universitas, melalui pendekatan teknologi rekayasa perangkat lunak sebagai upaya meningkatkan produktivitas dan kualitas proses pemantauan menjadi lebih efisien dan efektif. Adapun kelemahan dari penelitian ini hanya baru perancangan aplikasi, belum sampai ke pembangunan aplikasi.

Berdasarkan tinjauan pustaka tersebut, maka tujuan dari penelitian adalah untuk membangun sistem informasi sarana dan prasarana sekolah berbasis website pada SMK Bakti Purwokerto, dengan adanya sistem informasi ini dapat membantu staf sarana waka prasarana mulai dari proses pencarian barang, perekapan laporan hingga mengelompokkan data sarana prasarana. Dari penelitian sebelumnya diketahui bahwa sistem masih belum maksimal, beberapa bahkan masih berupa perancangan aplikasi. Sedangkan pada penelitian ini berfokus pada pembangunan sistem informasi sarana dan prasarana sekolah yang dilengkapi dengan teknik pelabelan $Q R$ Code pada barang, kemudian scan $Q R$ Code pengguna yang berguna untuk mempermudah proses peminjaman barang.

\section{Metode Penelitian}

Dalam penelitian ini, metode yang digunakan yaitu metode prototype sebagai pengembangan sistem. Penggunaan metode prototype merupakan metode yang paling cocok digunakan dalam membangun sistem informasi sarana dan prasarana sekolah pada SMK Bakti Purwokerto ini, karena untuk menyambungkan ketidakpahaman pengguna mengenai hal teknis dan memperjelas spesifikasi kebutuhan yang dibutuhkan oleh pengguna kepada pengembang perangkat lunak. 


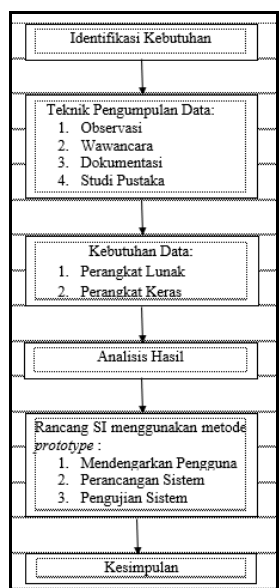

Gambar 1. Konsep Penelitian

Adapun konsep penelitian yang peneliti buat dapat dijelaskan bahwa:

Identifikasi Kebutuhan. Tahap ini proses identifikasi kebutuhan merupakan tahapan peneliti untuk mengidentifikasi masalah yang ada pada objek penelitian. Dalam tahap ini berisi mengenai perumusan masalah dan tujuan penelitian.

Teknik Pengumpulan Data. Tahap ini peneliti melakukan beberapa tahap teknik pengumpulan data yaitu: observasi, wawancara, dokumentasi, dan studi pustaka.

Kebutuhan Data. Dalam tahap ini, adapun untuk kebutuhan dalam penelitian ini yaitu kebutuhan perangkat lunak, perangkat keras, dan bahan penelitian.

Analisis Hasil. Dalam tahap ini peneliti menggunakan metode pengembangan sistem prototype guna membantu apakah pengembang aplikasi telah berada pada jalur yang benar selama proses pengembangan.

Rancang Sistem Informasi (SI) Menggunakan Metode Prototype. Dalam tahap ini merupakan tahap untuk melakukan perancangan Sistem Informasi terhadap apa yang akan digunakan dalam penelitian tersebut. Peneliti menggunakan metode pengembangan sistem prototype. Adapun tahap dari metode prototype yaitu mendengarkan pengguna dengan melakukan wawancara dengan pihak staf Wakil Kepala Sarana dan Prasarana, selanjutnya perancangan sistem dan proses pengodean, kemudian tahap pengujian yang digunakan yaitu metode beta testing yang biasa dikenal dengan istilah acceptance testing. Kemudian untuk mengetahui kondisi sistem yang di bangun apakah sudah sesuai kebutuhan atau belum yaitu menggunakan kuesioner, selanjutnya perhitungan hasil kuesioner dilakukan dengan menggunakan skala Likert.

Kesimpulan. Dalam tahap ini berisi ringkasan keseluruhan penelitian mulai dari peneliti mendengarkan pelanggan sampai dengan proses tahap hasil akhir dari penelitian.

\section{Hasil dan Pembahasan}

A. Analisis Hasil

Adapun konsep penelitiannya, peneliti menggunakan metode prototype sebagai pengembangan sistem. Untuk tahapan model prototype ini dimulai dari mengumpulkan apa saja yang menjadi kebutuhan pelanggan terhadap program yang akan dibuat. Adapun tahapan-tahapan dari model prototype yaitu sebagai berikut :

1. Prototype 1

A. Mendengarkan Pengguna

Dalam melakukan pengembangan sebuah sistem, adapun yang menjadi kebutuhan yang diperlukan yaitu :

a. Kebutuhan Pengguna

1) Kebutuhan Masukkan

Adapun yang menjadi kebutuhan masukan yaitu : Login, Data Admin, Data Pengguna, Data Menu Pengguna, Data Barang, Data Peminjaman, Data Pengembalian, Data Barang Hilang atau Rusak, dan Data Pengaturan.

2) Kebutuhan Proses

Adapun yang menjadi

kebutuhan proses yaitu : Proses Login, Proses Data Admin, Proses Data Pengguna, Proses Untuk Pengguna, Proses Data Barang, Proses Data Peminjaman Barang, Proses Data Barang Hilang atau Rusak, dan Proses Data Pengaturan.

3) Kebutuhan Keluaran Adapun yang menjadi kebutuhan keluaran Laporan Peminjaman Barang, Laporan Pengembalian Barang, Laporan Barang Hilang, Laporan Barang Rusak, Cetak Kode $Q R$ Barang, Kode $Q R$ User, dan Kode $Q R$ Transaksi.

4) Kebutuhan Fungsional

a. Kebutuhan Perangkat
Keras
Kebutuhan perangkat keras yang diperlukan untuk penerapan sistem informasi ini adalah satu unit komputer dengan memiliki spesifikasi Processor Intel® Core $^{\mathrm{TM}}$ i36006U CPU@2.00GHz 2.0 $\mathrm{GHz}$. sebagai alat untuk menjalankan aplikasi.
b. Kebutuhan Perangkat Lunak
Perangkat lunak atau software penunjang yang 
digunakan dalam penelitian

ini yaitu Windows 10

Professional 64-bit.

c. Kebutuhan Manusia

Kebutuhan manusia

(brain ware) pada sistem ini yaitu staf waka sarana dan prasarana sebagai admin yang memiliki hak akses penuh terhadap sistem dan beberapa pengguna yaitu siswa, guru, dan petugas TU yang hanya dapat melihat laporan barang yang dipinjamnya.

B. Perancangan Sistem

1. Perancangan UML

a) Use Case Diagram

Berikut ini adalah rancangan use case pada sistem informasi sarana dan prasarana sekolah di SMK Bakti Purwokerto.

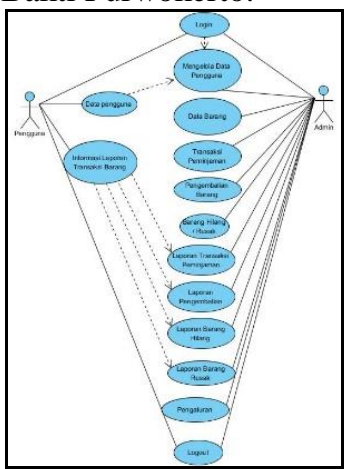

Gambar 2. Use Case Diagram

Pada gambar 2 menjelaskan bahwa dalam use case tersebut terdiri 2 otoritas yaitu admin yang dijalankan oleh staf sarana dan prasarana yang mengelola keseluruhan sistem. Dan pengguna yang terdiri dari siswa , guru dan petugas tata usaha hanya dapat melihat laporan barang yang dipinjamnya.

b) Activity Diagram

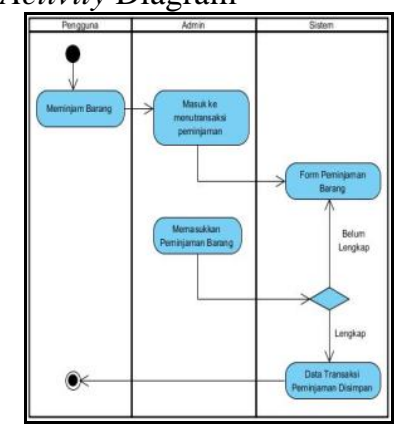

Gambar 3. Activity Diagram

Pada gambar 3 menjelaskan dua aktivitas, yaitu pengguna meminjam barang, dan admin masuk ke sistem menu transaksi peminjaman. Kemudian untuk admin mengisi form peminjaman barang, selanjutnya memasukkan peminjaman barang beserta jumlah barang yang akan dipinjam, jika belum lengkap maka akan kembali ke form peminjaman barang, namun jika data sudah terisi lengkap maka secara otomatis data akan tersimpan ke dalam sistem.

c) Sequence Diagram

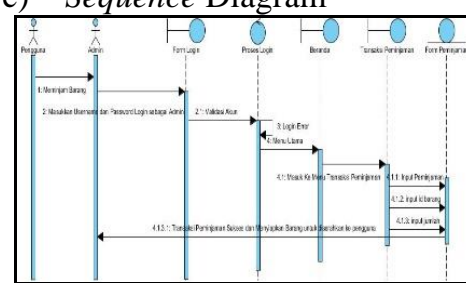

Gambar 4. Sequence Diagram

Pada gambar 4 menjelaskan bahwa pengguna meminjam barang kepada admin. Selanjutnya admin melakukan login dengan memasukkan username dan password sebagai admin untuk dapat masuk ke sistem. Setelah memasukkan username dan password terdapat validasi akun, jika terdapat kesalahan memasukkan akun maka secara otomatis kembali ke form login untuk mengisi ulang akun. namun jika berhasil maka admin masuk pada halaman utama.

Kemudian admin masuk ke menu transaksi, lalu pilih menu peminjaman. Setelah sub menu peminjaman tampil berupa form, admin memasukkan data ke dalam form peminjaman baru, dalam proses pengisian form peminjaman, admin memasukkan id peminjaman, id barang, dan jumlah barang apa saja yang hendak dipinjam, pengguna sesuai kebutuhan. Selanjutnya jika data sudah lengkap maka disimpan. Jika data sudah berhasil disimpan, admin menyiapkan barang yang akan dipinjam pengguna.

d) Class Diagram

Berikut ini merupakan perancangan class diagram sistem informasi sarana dan prasarana sekolah berbasis website pada SMK Bakti Purwokerto. 


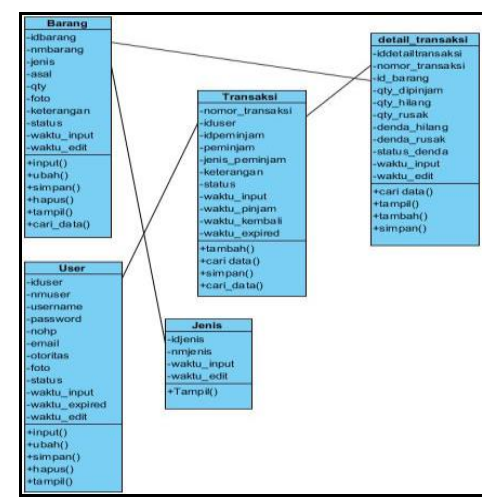

Gambar 5. Class Diagram

Pada gambar 5 menjelaskan mengenai class diagram dari sistem informasi sarana dan prasarana sekolah berbasis website SMK Bakti Purwokerto. Sistem tersebut terdiri dari 5 class yang saling terhubung yaitu barang, user, jenis, transaksi, dan detail transaksi.

2. Perancangan Database

Secara struktural tabel yang digunakan pada sistem ini seperti tabel barang, tabel user, tabel transaksi, tabel detail transaksi, dan tabel jenis.

3. Implementasi Antar Muka

A. Antar Muka Sisi Admin

a) Halaman Login

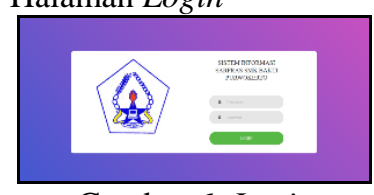

Pada

Gambar 6. Login

merupakan tampilan login.

Halaman ini berfungsi untuk melakukan proses login yang dilakukan oleh administrator dan pengguna. Pada form terdapat dua textbox yaitu username dan password, serta satu tombol yaitu login.

b) Halaman Beranda

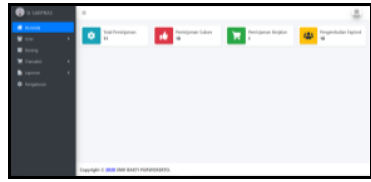

Gambar 7. Beranda

Pada gambar

merupakan tampilan beranda administrator. Pada halaman ini terdapat beberapa menu yang dapat digunakan untuk mengelola administrator yaitu menu user yang terdiri dari 4 sub menu yaitu admin, siswa, guru, dan petugas. menu barang, menu transaksi yang terdiri dari 3 sub menu yaitu peminjaman, pengembalian dan barang hilang atau rusak. menu laporan yang terdiri dari 4 sub menu yaitu laporan peminjaman, pengembalian, barang hilang, dan barang rusak. Selanjutnya menu pengaturan.

c) Halaman Menu User

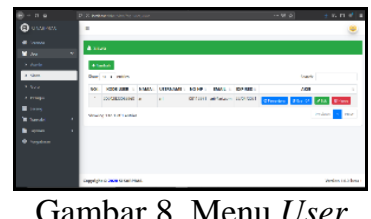

Pada gambar 8 merupakan tampilan dari sub menu yang ada di menu user yaitu siswa. Dalam halaman tersebut dapat mengelola pengguna diantaranya tambah data, edit, hapus, dan membuat kode $Q R$ pengguna.

d) $Q R$ User

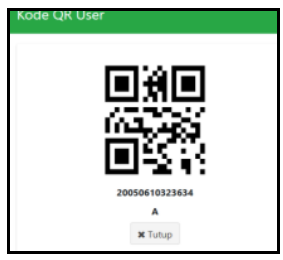

Gambar 9. QR User
Pada gambar 9 merupakan tampilan dari $Q R$ user yang berfungsi sebagai identitas pada saat peminjaman barang. Dalam tampilan tersebut terdiri dari kode $Q R$, nomor identitas pengguna, dan satu tombol tutup.

e) Halaman Data Barang

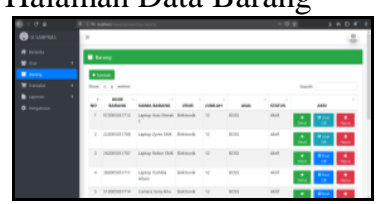

Gambar 10. Data Barang

Pada gambar 10 merupakan tampilan dari menu barang. Dalam halaman tersebut dapat mengelola data barang diantaranya tambah data, edit, hapus, membuat dan mencetak kode QR barang. Kode $Q R$ tersebut berfungsi untuk mengelompokkan barang. f) Halaman Peminjaman 


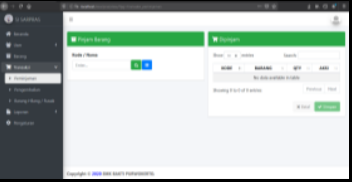

Gambar 11. Halaman

Peminjaman

Pada gambar 11 merupakan tampilan dari halaman peminjaman. Halaman tersebut berfungsi untuk mengelola peminjaman barang. Dalam halaman tersebut terdiri dari form pinjam barang yang terdiri dari 1 text box pencarian kode, tombol pencarian, dan tombol scan kode $Q R$ peminjam barang. Dalam form pinjam barang juga terdiri dari daftar barang apa saja yang tersedia seperti kode, barang, stok, $Q T Y$, dan satu buah tombol aksi.

g) Scan $Q R$ Peminjam

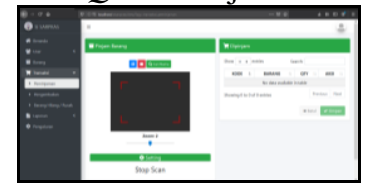

Gambar 12. Scan $Q R$

Peminjam

Pada gambar 12 merupakan tampilan scan $Q R$ peminjam yang berfungsi untuk mempermudah proses peminjaman. Dalam tampilan tersebut terdiri dari 4 tombol yaitu tombol $Q R$, tombol stop, tombol cari nama, dan tombol pengaturan pencahayaan kamera. Kemudian terdapat 1 buah scan kamera.

h) Halaman Laporan Peminjaman

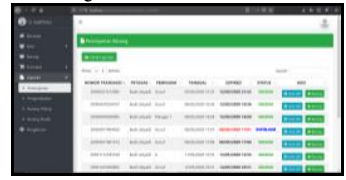

Gambar 13. Laporan Peminjaman

Pada gambar 13 merupakan tampilan dari laporan peminjaman. Laporan tersebut berfungsi untuk merekap data secara rentang waktu yang dibutuhkan admin. Dalam halaman tersebut terdiri dari 2 buah tombol cetak laporan yang di dalamnya bisa mencetak output laporan pdf dan excel, Kemudian tombol barang berfungsi untuk melihat daftar barang yang dipinjam. Selanjutnya ada nomor transaksi, petugas (admin) peminjam, tanggal peminjaan, tanggal expired, dan status.

i) Pengaturan

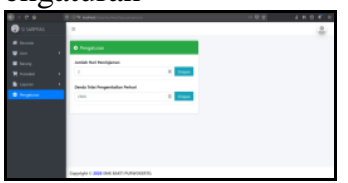

Gambar 14. Pengaturan

Pada gambar 14 merupakan tampilan dari pengaturan yang berfungsi untuk mengelola batas jumlah peminjaman dan besarnya denda. Dalam halaman tersebut terdiri dari 2 text box yaitu memasukkan jumlah hari peminjaman dan denda telat pengembalian per hari. Dan 2 buah tombol simpan.

B. Antar Muka Sisi Pengguna a) Beranda Pengguna

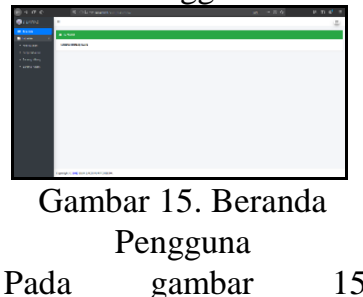
merupakan tampilan dari beranda pengguna yang terdiri dari menu beranda dan menu laporan.

b) Laporan Peminjaman Pengguna

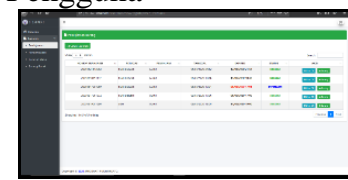

Gambar 16. Laporan

Peminjaman Pengguna

Pada gambar 16 merupakan tampilan dari laporan peminjaman pengguna. Laporan tersebut berfungsi untuk merekap data secara rentang waktu yang dibutuhkan pengguna. Yang membedakan laporan peminjaman pengguna dengan admin yaitu terletak pada personal. Jadi pada 
laporan pengguna itu hanya dapat melihat laporan peminjaman barang yang dipinjam olehnya, sedangkan jika admin melihat laporan peminjaman secara keseluruhan peminjam. Dalam halaman tersebut terdiri dari 1 buah tombol cetak laporan yang di dalamnya bisa mencetak output laporan $p d f$ dan excel, Kemudian dalam aksi terdiri dari 2 tombol barang berfungsi untuk melihat daftar barang yang dipinjam, dan tombol $Q R$ code yang berfungsi untuk melihat kode $Q R$ transaksi peminjaman. Selanjutnya ada nomor transaksi, petugas (admin) peminjam, tanggal peminjaan, tanggal expired, dan status.

c) Profil Pengguna

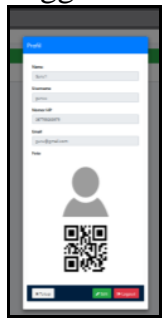

Gambar 17. Profil

Pengguna

Pada gambar 17 merupakan halaman dari profil pengguna. Halaman tersebut berfungsi untuk mengelola data pengguna itu sendiri seperti mengubah data dan menambahkan foto profil. Kemudian dalam halaman tersebut terdapat nama, username, nomor hp, email, foto profil, kode $Q R$ pengguna, dan 3 buah tombol yaitu edit, logout, dan tombol tutup.

\section{Pengujian}

Pengujian dilakukan menggunakan pengujian unit testing dan acceptance testing. Pengujian unit testing dilakukan untuk menguji kode-kode program dalam satuan unit terkecil. Pengujian ini dilakukan setiap kali penulisan kode-kode program pada fitur sistem informasi sarana dan prasarana sekolah pada SMK Bakti Purwokerto yang telah dibuat untuk mengetahui apakah fitur tersebut sesuai dengan apa yang diharapkan atau tidak.
Sedangkan acceptance testing dilaksanakan pada tanggal 10 Mei 2020 yang bertujuan untuk mengetahui apakah sistem informasi sarana dan prasarana sekolah pada SMK Bakti Purwokerto yang dibangun telah memenuhi kriteria penerimaan dan apakah sistem informasi sarana dan prasarana sekolah ini dapat diterima oleh pengguna atau tidak.

Acceptance testing atau istilah dari Beta Testing dilakukan kepada Staf Wakil Kepala Sarana dan Prasarana, Guru, Siswa, dan Petugas TU SMK Bakti Purwokerto. Jumlah responden yang digunakan sebagai sample dalam pelaksanaan kuesioner pada tanggal 15 Mei 2020 sebanyak 88 orang yang terdiri dari 1 staf Wakil Kepala Sarana dan Prasarana, 29 Guru, 50 Siswa, dan 8 Petugas TU. Adapun jumlah 88 orang civitas akademik sekolah berdasarkan jumlah rata-rata peminjam barang setiap harinya. Pertanyaan yang digunakan dalam kuesioner SISARPRAS (Sistem Informasi Sarana dan Prasarana Sekolah) yang terdiri dari 6 pertanyaan.

Tabel 1. Hasil jumlah skor dan prsentase kuesioner SISARPRAS

\begin{tabular}{|l|l|c|c|}
\hline $\begin{array}{l}\text { N } \\
\text { o. }\end{array}$ & Pertanyaan & $\sum_{\text {Skor }}$ & Prsentase\% \\
\hline 1 & $\begin{array}{l}\text { Sistem mudah } \\
\text { dioperasikan }\end{array}$ & 398 & 90,4 \\
\hline 2 & $\begin{array}{l}\text { Beberapa } \\
\text { menu dan } \\
\text { tombol dalam } \\
\text { aplikasi } \\
\text { mudah } \\
\text { dipahami }\end{array}$ & 406 & 92,3 \\
\hline 3 & $\begin{array}{l}\text { Sistem sesuai } \\
\text { kebutuhan }\end{array}$ & 381 & 86,6 \\
\hline 4 & $\begin{array}{l}\text { Sistem } \\
\text { membantu } \\
\text { mengelompok } \\
\text { kan barang } \\
\text { dengan baik }\end{array}$ & 383 & 87,4 \\
\hline 5 & $\begin{array}{l}\text { Fitur dalam } \\
\text { sistem sudah } \\
\text { berfungsi } \\
\text { dengan baik }\end{array}$ & 381 & 86,6 \\
\hline 6 & $\begin{array}{l}\text { Sistem dapat } \\
\text { membantu } \\
\text { pemantauan } \\
\text { proses } \\
\text { peminjaman } \\
\text { barang }\end{array}$ & 390 & 88,6 \\
\hline
\end{tabular}

Setelah menghitung rumus indeks, diperlukan kriteria interpretasi skor berdasarkan interval (jarak). Rumus interval dalam bentuk persentase adalah sebagai berikut :

Interval $=100 /$ jarak skor $($ Likert $)$ 
Maka Interval $=100 / 5=20$

Sehingga dihasilkan interval 20. Ini merupakan interval dari terendah $0 \%$ dan tertinggi $100 \%$.

Tabel 2. Rating Scale

\begin{tabular}{|l|l|}
\hline Nilai & Kriteria \\
\hline $81 \%-100 \%$ & Sangat Baik \\
\hline $61 \%-80 \%$ & Baik \\
\hline $41 \%-60 \%$ & Cukup Baik \\
\hline $21 \%-40 \%$ & Tidak Baik \\
\hline $0 \%-20 \%$ & Sangat Tidak Baik \\
\hline
\end{tabular}

Dari hasil perhitungan indeks maka dapat diambil rata-rata indeks hasil pengujian sistem informasi sarana dan prasarana sekolah pada SMK Bakti Purwokerto sebagai berikut :

Rata-rata indeks $=(90,4 \%+92,3 \%+$ $86,6 \%+87,4 \%+86,6 \%+88,6 \%) / 6=$ $88,65 \%$

Jadi didapatkan hasil presentase nilai sebesar 88,65\% sehingga termasuk dalam kriteria Sangat Baik.

\section{Kesimpulan dan Saran}

Berdasarkan hasil analisis dan pembahasan yang dilakukan peneliti maka dihasilkan sebuah sistem informasi sarana dan prasarana sekolah berbasis website pada SMK Bakti Purwokerto, maka dapat diambil kesimpulan sebagai berikut:

Sistem informasi yang diusulkan dapat mencetak $Q R$ Code barang dapat mempermudah admin yang dijalankan oleh staf wakil kepala sarana dan prasarana dalam mengelompokkan barang.

Sistem informasi yang diusulkan dapat mencari nama barang, dan transaksi peminjaman barang yang sudah tersimpan di database jika sewaktu-waktu lupa menyimpan buku alat dan peminjaman.

Sistem informasi yang diusulkan dapat mengetahui laporan mulai dari peminjaman sampai dengan laporan barang hilang dalam skala periode tertentu baik itu dengan format excel ataupun $p d f$ sehingga mempermudah staf wakil kepala sarana dan prasarana dalam melakukan pelaporan kepada kepala sekolah.

Dengan metode prototype, pembangunan sistem informasi sarana dan prasarana sekolah pada SMK Bakti Purwokerto dapat dibuat lebih cepat dan dapat memenuhi kebutuhan pengguna dilihat dari hasil perhitungan kuesioner dengan metode pengujian beta testing atau biasa dikenal dengan istilah dari acceptance testing yang dihasilkan nilai sebesar $88,65 \%$ tergolong dalam kriteria sangat baik.

Adapun saran untuk penelitian selanjutnya adalah sebagai berikut:

Dari hasil penelitian dapat dikembangkan untuk penelitian selanjutnya dengan ditambahkan fitur pembelian barang.

Sistem informasi ini dapat dikembangkan dengan adanya fitur pengajuan peminjaman bagi pengguna.

\section{Daftar Pustaka}

[1] A. Hanif, "Sistem Informasi Sederhana Menggunakan Spreadsheet dan Macro Untuk Usaha Mikro Informal," Semin. Nas. Teknol. Komput. Sains, vol. 1, no. 1, pp. 851-855, 2019.

M. Y. Kurniawan, "Administrasi Sarana dan Prasarana Belajar,” pp. 1-6, 2019.

[3] M. Chandrawati and M. B. Sanjaya, "Aplikasi Peminjaman Sarana Dan Prasarana Olahraga Berbasis Web Studi Kasus: SMA Negeri 1 Baleendah," vol. 5, no. 2, pp. 1040-1046, 2019.

[4] Z. Y. Mubarak, E. Noor, F. Destyanto, K. T. Nugroho, M. I. Mustofa, and A. M. Arif, "Perancangan Sistem Informasi Kesehatan Di Tingkat Posyandu Cilacap Selatan Kabupaten Cilacap," Semnasteknomedia Online, vol. 5, no. 1, pp. 1-2-271, 2017.

[5] P. R. Putra, R. P. A. G. I. Agung, and P. Rahardjo, "Rancang Bangun Vending Machine," vol. 6 , no. 2, pp. 102-111, 2019.

[6] S. P. Indriyani and D. Kurniadi, "Rancang Bangun Sistem Informasi Pelayanan Unit Sistem Informasi," vol. 6, no. October, pp. 68-75, 2017.

[7] M. Destiningrum and Q. J. Adrian, "Sistem Informasi Penjadwalan Dokter Berbassis Web Dengan Menggunakan Framework Codeigniter (Studi Kasus: Rumah Sakit Yukum Medical Centre)," J. Teknoinfo, vol. 11, no. 2, p. 30, 2017, doi: 10.33365/jti.v11i2.24.

[8] A. Triyono, "Upaya melengkapi sarana dan prasarana pendidikan madrasah," El-Hamra, vol. 04, 2019.

[9] A. L. Ghozali, K. A. Cahyanto, and D. Anwar, "Implementasi Sistem Pendaftaran Dan Edukasi Pencak Silat Budi Asih Se-Ciayumajakuning Berbasis Website Dengan Framework Codeigniter ( Ci )," vol. 5, no. 2, pp. 14-18, 2019.

[10] N. Rubiati and S. W. Harahap, "Aplikasi Absensi Siswa Menggunakan Qr Code Dengan Bahasa Pemrograman Php Di Smkit Zunurain Aqila Zahra Di Pelintung," Informatika, vol. 11, no. 1, p. 62, 2019, doi: 10.36723/juri.v11i1.156.

[11] A. A. Pradipta, Y. A. Prasetyo, and N. Ambarsari, "Pengembangan Web E-Commerce Bojana Sari Menggunakan Metode Prototype," e-Proceeding Eng., vol. 2, no. 1, pp. 1042-1056, 2015.

[12] A. Rochman, R. Tullah, and A. Rahman, "Perancangan Sistem Informasi Data Pasien di Klinik Aulia Medika Pasarkemis," Sisfotek Glob., vol. 9, no. 1, pp. 1-6, 2019.

[13] Awaludin and E. Saputra, "Sistem Informasi Manajemen Sarana Prasarana Sekolah (Studi Kasus: Dinas Pendidikan dan Kebudayaan Kabupaten Siak)," Pros. Sentia, vol. 2, no. 12, pp. 6-13, 2016.

[14] V. Alawiyah, Poningsih, S. R. Andani, and Solikhun, "Perancangan Aplikasi Pendataan Sarana dan Prasarana Pada SD Yayasan Pendidikan Kartini Handayani," Sainteks 2020, vol. 1, pp. 214-217, 2020.

[15] I. S. Pratama, Nawassyarif, and J. Aliyah, "Pengembangan Sistem Informasi Sarana Dan Prasarana Di Universitas Tetknologi Sumbawa (UTS) Berbasis Web," vol. 1, no. 1, pp. 39-49, 2019. 
Priono, Sistem Informasi Sarana dan Prasarana Sekolah Berbasis Website SMK Bakti Purwokerto

[16] R. Annisa, M. Ugiarto, and Rosmasari, "Sistem Inventaris Sarana dan Prasarana Di Fakultas Ilmu Komputer dan Teknologi Informasi Universitas Mulawarman," Pros. Semin. Ilmu Komput. dan Teknol. Inf., vol. 2, no. 1, pp. 69-72, 2017.

[17] L. A. Abdillah, L. Atika, K. Kurniawan, and F. Purwaningtias, "Prototype Software Monitoring Sarana dan Prasarana Perguruan Tinggi," J. Sist. Inf. Bisnis, vol. 9, no. 1, p. 18, 2019, doi: 10.21456/vol9iss1pp18-24. 